\title{
KONSEP PEMIMPIN IDEAL MENURUT AL-GHAZĀLī
}

\author{
Ade Afriansyah \\ IAIN Palangka Raya
}

\begin{abstract}
Abū Hamid Muhammad ibn Muḥammad ibn Muhammad al-Ghazālī al-Ṭūsì al-Sāafi'i, known as al-Ghazāli an hujjah of Islam (1058-1111 AD) with a deeper concept of leader thinking, emphasizes the substantial aspect of the value of religious teaching rather than the -seg formal-symbolic, unifying what has been separated from the leader figure, the leader must come from the people with the people's choice. The ideal leader type according to al-Ghazāli is a leader who possesses intellectuality, religion and morality, is able to influence the environment which is led, and is able to cure destruction and destruction within the nation or organization, and bring a just and prosperous society by upholding the scientific, moral based on religion.
\end{abstract}

Keywords: Leader, Leadership, al-Ghazali.

\section{PEMIMPIN IDEAL}

Muhammad bin Muhammad bin Muhammad bin Ahmad atau Abū Ḥamid Muḥammad ibn Muḥammad ibn Muhammad al-Ghazālī al-Ṭūsī al-Ṣāfi' 'i, ${ }^{1}$ lebih dikenal dengan nama alGhazālī dengan gelar Huj-jat al-Islām yang mengandung arti: bukti kebenaran Islam, ${ }^{2}$ merupakan seorang filosof dan teolog muslim Persia, yang dikenal sebagai Algazel di dunia Barat pada abad Pertengahan. Dilahirkan di kampung kecil Ghazalah, kabupaten Thus (sekarang dekat Meshed), propinsi Khurasan, wilayah Persi (Iran Utara) pada 1058 M /450 $\mathrm{H}^{3}{ }^{3}$ dan meninggal dunia di Thus pada $1111 / 14$ Jumadil Akhir $505 \mathrm{H}$ dalam umur 52-53 tahun.

Al-Ghazālī merumuskan tipe pemimpin ideal, yang lahir dari berbagai kepemimpinan masa itu. Perpaduan akal dan batin yang dimiliki al-Ghazālī melahirkan buah pemikiran pemimpin baru, pemimpin yang mencerminkan figur kepemimpinan Nabi Muhammad Saw. Rumusan tentang pemimpin yang disusun oleh al-Ghazālī berawal dari kekecewaannya terhadap pemimpin, raja, ulama, dan pejabat pada masa Dinasti Saljuk yang mengalami kemunduran, karena terjadinya perebutan tahta dan gangguan stabilitas keamanan dalam negeri. Korupsi nepotisme, ketidakadilan, penyuapan, serta kekejaman.

Pemimpin ideal bagi al-Ghazālī adalah pemimpin yang memiliki intelektualitas yang luas, pemafhuman agama yang mendalam, serta akhlak yang mulia, seperti yang dicontohkan Muhammad dan para sahabat. Inilah sosok pemimpin yang diinginkan oleh al-Ghazāī, seorang pemimpin yang membawa perubahan dan pembaruan, menggerakkan bawahan melalui iman dan pengetahuan, dan mencerminkan akhlak yang mulia.

Untuk menjadi seorang pemimpin ideal, ia harus memiliki beberapa kelebihan dibanding dengan anggota-anggota yang lainnya, karena kelebihan-kelebihan itulah seorang

\footnotetext{
${ }^{1}$ Lihat First Encyclopedia of Islam, 1913-1936, New York: Leiden, 1987, hlm. 146

${ }^{2}$ Lihat Ensiklopedi Islam Indonesia, Jakarta: Djambatan, 1992, hlm. 257.

${ }^{3}$ Ahmad Hanafi, Pengantar Filsafat Islam, Jakarta; Bulan Bintang, 1990, hlm. 135.
} 
pemimpin menjadi berwibawa dan dipatuhi oleh bawahannya. Persyaratan pemimpin selalu terkait dengan tiga hal penting, yaitu: kekuasaan, kewibawaan dan kemampuan. Kekuasaan ialah kekuatan, otoritas, dan legalitas yang memberikan wewenang kepada pemimpin, guna memengaruhi dan menggerakan bawahan untuk berbuat sesuatu. Kewibawaan ialah kelebihan, keunggulan, dan keutamaan sehingga mampu mengatur orang lain, sehingga orang itu patuh pada pimpinan, dan bersedia melakukan perbuatan-perbuatan tertentu. Kemampuan ialah segala daya, kesanggupan, kekuatan, dan kecakapan atau keterampilan teknis maupun sosial, yang dianggap melebihi dari kemampuan anggota biasa. ${ }^{4}$

Pendapat al-Ghazālī hampir sama dengan al-Mawardi tentang kriteria pemimpin yang ideal, yakni seorang yang mampu berbuat adil di antara masyarakat (tidak nepotis), melindungi rakyat dari kerusakan dan kriminalitas, serta tidak dzalim (tirani). Selain itu, seorang pemimpin harus memiliki integritas dan penguasaan dalam bidang ilmu negara serta agama, agar dalam dalam menentukan kebijakan, pemimpin bisa berijtihad dengan benar, sehat panca inderanya (mata, pendengaran, lisan tidak terganggu yang dapat menghalangi ia menjalankan tugas), keempat, anggota badannya normal tidak cacat yang dapat mengganggu tugas, pemberani, memiliki keahlian siasat perang, dan kemampuan intelektual untuk mengatur kemaslahatan rakyat. ${ }^{5}$

Pemimpin dalam Islam merupakan kepemimpinan spiritual dan intelektual yang pada dasarnya adalah amanah, yaitu kepercayaan yang harus dijaga dan ditunaikan dengan sebaikbaiknya. ${ }^{6}$ Kepemimpinan juga mengandung makna pelayanan kepada masyarakat yang dipimpinnya. Pemimpin bukan hanya sekadar wewenang atau kewenangan, tetapi pelayanan dan penghidmatan kepada orang-orang yang dipimpin, serta kepemimpinan mengandung makna keteladanan dan kepeloporan. Pelopor penggerak dan perubahan dan kemajuan. Kepemimpinan Islam memiliki tiga kunci yakni: tanggung jawab (amānah), pelayanan (khidmah), dan kepeloporan (quwah hasanah). ${ }^{7}$

Hakikat kepemimpinan menurut al-Ghazālī adalah pengaruh. Pemimpin adalah orang yang berpengaruh atau orang yang memiliki pengaruh yang kuat di masyarakat. Tidak disebut pemimpin bila tak memiliki pengaruh, pengaruh dengan artian pengaruh kedudukan pemimpin di mata dan di hati manusia. ${ }^{8}$ Pengaruh itu timbul karena pemimpin memiliki nilainilai yang mulia, seperti pemimpin yang intelektualitas yang luas, pemafhuman agama yang mendalam, serta akhlak yang mulia. Pemimpin yang memiliki tiga poin utama itulah yang mampu mempertahankan kedudukan seorang pemimpin, dan menjadi corak khas dalam pemikiran pemimpin al-Ghazālī.

\section{Intelektualitas}

Akal diibaratkan sebagai cahaya yang menyusup kedalam sanubari manusia, dan membimbingnya memahami segala sesuatu. Orang yang menolak makna ini, dan membatasi pengertian akal hanya sebatas alat untuk memahami ilmu-ilmu yang fardu, maka dia telah melakukan kekeliruan. Akal adalah sifat yang mampu membedakan eskistensi manusia dari

\footnotetext{
${ }^{4}$ Kartini Kartono, Pemimpin dan Kepemimpinan, Jakarta: Raja Grafindo Persada, 1990, hlm. 36.

${ }^{5}$ Al-Ghazālī, Ihyā' 'Ulum̄ ad-Dīn, I, Semarang: Toha Putra, t.t, hlm. 22.

${ }^{6}$ M. Quraish Shihab, Menabur Pesan Ilahi, Jakarta; Lentera Hati, 2006, cet. I, hlm. 379.

${ }^{7}$ Ibid., hlm. 384.

${ }^{8}$ Al-Ghazālī, Ihya' Ulumuddin, II, Beirut: Dar Kutub al-Ilmiyah, t.t ., hlm. 295.
} 
binatang. Akal yang difungsikan dengan baik akan menunjukkan manusia ke jalan ilmu yang bersifat teori yang kemudian memahami pemikiran yang bersifat abstrak. ${ }^{9}$

Dalam penjelasan kitab Ihȳa' 'Ulum̄ ad-Dīn juz I, al-Ghazālī membagi tingkatan akal menjadi empat, akal manusia laksana cermin yang dapat dibedakan dari benda-benda fisik material lainnya, dikarenakan khususnya dalam urusan mengindentifikasi bentuk maupun warna, yaitu sifatnya yang bercahaya. ${ }^{10}$ Keempat tingkatan akal itu sebagai berikut: ${ }^{11}$

1. Akal berarti kecerdasan, dimiliki oleh setiap manusia, yang membedakannya dengan hewan-hewan dan makhluk yang lainnya, yaitu arti yang umum dipakai orang. Akal inilah yang dibawa oleh manusia semenjak lahir sebagai modal pokok hidup. Sebagaimana hubungan antara mata dan penglihatan atas apa saja yang disinarinya. Akal berfungsi sebagai memantulkan dan menyebarkan ilmu. ${ }^{12}$

2. Akal berarti pengertian, yang tumbuh pada manusia setelah akalnya yang pertama mulai berjalan, dan berkembang semenjak dari kecilnya, terus meningkat naik pada usia muda, menjadi dewasa dan selanjutnya. Akal inilah yang telah mengerti akan benar dan salah, buruk dan baik, tercela dan menurut pengertian yang bisa. ${ }^{13}$

3. Akal berarti pengetahuan, yang timbul pengajaran dan pengalaman, yang telah menpelajari sesuatu dengan saksama. Akal inilah yang telah melahirkan ilmu pengetahuan yang begitu banyaknya, begitu tingginya dan begitu luasnya. Di dalam segala bidang, baik lapangan alam dan pengalaman, ia melahirkan ilmu-ilmu yang dinamakan "natural sciences", maupun di lapangan masyarakat, ia melahirkan ilmu-ilmu yang dinamakan social sciences. ${ }^{14}$

4. Akal berarti ma'rifah, yang merupakan puncak dari segala tingkat akal, yaitu keinsafan rohani manusia yang menyadari akibat-akibat sesuatu, dan membawanya kepada keluhuran budi akhlak, serta memimpinnya kepada Tuhan Yang Maha Esa. $^{15}$

Pengertian akal yang pertama merupakan dasar dan sumbernya. Sedangkan pengertian yang kedua merupakan cabang dari akal, yang mendekati pengertian pertama. Kedua pengertian ini timbul disebabkan oleh faktor alamiah. Pengertian ketiga adalah rating dari pengertian pertama dan kedua. Pengertian keempat merupakan hasil tertinggi fungsi akal, dan menjadi tujuan akhir dari akal. Adapun dua pengertian yang terakhir harus diupayakan dan dicari untuk bisa mencapainya.

Akal merupakan sebutan untuk naluri alamiah, tetapi perwujudan dari akal dapat diketahui dari apa yang dimunculkannya. Orang yang berakal adalah orang yang paling bertakwa kepada Allah Swt. Sebab ketakwaan kepada Allah adalah buah dari akal yang difungsikan dengan benar. Ilmu dan pengetahuan tidak berasal dari luar, keduanya berada di balik akal yang merupakan sumber alamiah, seperti air yang tersembunyi di dalam tanah.

\footnotetext{
${ }^{9}$ Al-Ghazālì, Ihyā', I, hlm. 84.

${ }^{10}$ Ibid., hlm. 85.

${ }^{11}$ Zainal Abidin Ahamad, Konsepsi Negara Bermoral Menurut Imam al-Ghazālī, Jakarta: Bulan Bintang, 1975, hlm. 68-69.

${ }^{12}$ Al-Ghazālī, Ihyā', I, hlm. 85.

13 Ahamad, Konsepsi, hlm. 68.

${ }^{14}$ Ibid. hlm. 69.

15 Ibid.
} 
Apabila sumur digali, air akan memancar keluar dari dalamnya, dan bukan sesuatu yang baru yang kemudian dituangkan di atasnya. ${ }^{16}$ Ilmu dicari karena nilai mulia dari ilmu itu sendiri, dan tujuan akhir dari kehidupan manusia di dunia ini adalah kebahagiaan, dan cara mencapai kebahagiaan itu dengan ilmu.

Al-Ghazālī menghubungkan ilmu pengetahuan dengan agama yang dikehendaki oleh kaum sufi, dan dari penggabungan semuanya itu menjadilah ma 'rifah yang menjadi tingkat yang tertinggi di dalam pengetahuan dan kesadaran manusia kepada Tuhan. Di sinilah keahlian al-Ghazālī memecahkan dan menguraikan persoalan ma 'rifah itu secara ilmiah, dan dapat dibawa ke tengah masyarakat umum. Bukan ma'rifak mistik, paham kaum sufi yang campur-aduk. Paham itu juga dinamakan irfān, dengan nama asli gnosticism, yaitu menggabungkan antara falsafah Yunani dengan mistik-mistik dunia Timur, yang sudah menimbulkan kekacauan di dalam agama Kristen sejak abad ke-2 M. ${ }^{17}$ Al-Ghazālī memelopori untuk mengambalikan paham sufi tentang ma'rifah kepada paham Ahli alSunnah wal Jamā'ah, yang bersandarkan pada Alquran dan Hadis. Ma'rifah merupakan perpaduan ilmu pengetahuan dan keimanan (agama), yang kemudian munculah hasrat beramal yang kuat, dan akhlak dapat tercerminkan. Dalam ma 'rifah memancarkan niat yang ikhlas dan kemauan yang kuat, yang menjadi pokok pangkal amal dan akhlak.

Ilmu pengetahuan dan agama memiliki hubungan erat yang tak terpatahkan, hal ini penting bagi kehidupan manusia. Al-Ghazālī dan al-Farabi mengemukakan hal ini dalam konsepsi politiknya, tentang kecerdasan akal dan sifat kenabian/keagamaan, yang dinamakan al-'Aqlu wa al-Nubuwwah = Human Intellect and Prophethood. Ditegaskan bahwa setiap warga negara harus memiliki kecerdasan akal yang dituntun oleh jiwa keagamaan, sedang kepala negara sebagai pemimpin harus mempunyai sifat-sifat kenabian yang luhur, atau sekurang-kurangnya bersifat keagamaan.

Untuk mencapai hakikat ma'rifah yang dimaksud al-Ghazālī dengan ilmu pengetahuan yang sejati, dengan berdasarkan pada Alquran dan Hadis, bahwa ada lima macam yang dapat dipergunakan untuk menjadi timbangan yang dinamakan "pancatimbangan". Adapun timbangan itu dibagi menjadi lima, itu: ${ }^{18}$ Timbangan "perbandingan" ( $t a$ 'dul) yang dipecah menjadi tiga macam: pertama, perbandingan yang besar, yang didasarkan kepada pemikiran dan ilmu pengetahuan. Kedua, perbandingan menengah, yang didasarkan kepada pengalaman. Ketiga, perbandingan kecil-rendah yang didasarkan pada perasaan dan panca indra. Keempat, timbangan "kemestian" (talazum), yang didasarkan pada suatu kebenaran, yang memastikan timbulnya kebenaran selanjutnya. Timbangan ini dapat ditimbulkan oleh intuisi manusia, yang sering dinamakan "panca-indra" yang keenam. Kelima, timbangan "pertentangan" ( $t a$ 'arudh), yang didasarkan pada pertentangan antara sesuatu dengan sesuatu yang lainnya untuk menimbulkan kebenaran. Karena adanya tese dan anti-tese, maka timbulah kebenaran sejati yang merupakan sintese. Al-Ghazālī menganjurkan untuk memakai segala macam timbangan itu dengan seluas-luasnya dan sedalam-dalamnya untuk mencerdaskan akal dan memperkuat iman.

\footnotetext{
${ }^{16}$ Al-Ghazālī, Ihyā', I, hlm. 85-86.

${ }_{17}$ Ahamad, Konsepsi, hlm. 134.

${ }^{18}$ Ibid., hlm. 71-73.
} 
Al-Ghazālī mengambarkan bahwasanya hati manusia mempunyai dua pintu yang berhubungan satu dengan yang lainnya: ${ }^{19}$ pertama, pintu luar yang menghubungkan manusia dengan segala makhluk (alam syahadah), ialah pintu pengetahuan yang melalui akal dan panca indra, dinamakan ilmu. Kedua, pintu dalam yang menghubungkan manusia dengan Tuhan (alam malakut), merupakan pintu ilham atau wahyu, dinamakan ma'rifah. Pintu itu dapat dilalui dengan belajar, sedangkan pintu dalam dapat dilalui dengan perantaraan berlatih (mujahadah). Seorang yang dapat mencapai tingkat tertinggi dari ilmu pengetahuan (pintu luar), berhak dinamakan ulama (bagi ilmu-ilmu agama) atau sarjana (bagi ilmu-ilmu umum), dan orang yang mencapai tingkat tertinggi dalam ma 'rifah (pintu dalam), dapat dinamakan wali, dengan ijazahnya yang dinamakan keramah (kemuliaan).

Pintu luar menerima segala petunjuk dan pimpinan dari semua alam yang lahir, baik melalui pendidikan, pergaulan, dan latihan, maupun dengan melalui panca-indra yang lima ditambah dengan indra yang keenam ialah akal pikiran, ilmu yang berasalkan dari luar ini dinamakan al-Ghazālī sebagai ilmu mu'amalah. Adapun pintu dalam dari hati, menerima petunjuk dari suatu sumber yang bening, bersih, dan tiada tandingan, yaitu wahyu atau ilham. Ilmu yang kedua ini namanya ilmu mukasyafah. ${ }^{20}$

Dengan ilmu pengetahuan manusia mencapai tingkat kecerdasan sempurna, agama dan akhlak untuk mensucikan dan meluhurkan jiwanya. Bila ketiganya tidak ada dalam diri pemimpin, maka akan ada tiga bencana yang dimaksudkan al-Ghazālī: pertama, at-taqlīd wal jumūd (fanatisme, taklid buta, dan sifat jumud beragama). Agama tanpa ilmu pengetahuan, yang menyebabkan hilangnya moral agama tanpa ilmu berarti taqlìd, dan taqlìd yang menjadi jumūd, yang berarti permusuhan yang menghancurkan moral. Taqlīd dan jumūd menyebarkan bibit-bibit fanatik.

Kedua, zandaqah wal juhūd (rationalism and atheism, pendewaan akal dan antiTuhan), dalam buku al-Ghazālī di dalam Tahāfut al-Falāsifah menyangkal 20 buah kesalahan para filosof Muslim beserta pendahulu-pendahulu mereka yang berpaham teistik di Yunani. Para filosof yang disangkal oleh al-Ghazālī ini terbagi ke dalam tiga kelompok: ${ }^{21}$ (1) Filosof-filosof materialistik (dahriyyūn). (2) Filosof-filosof naturalis atau desitik (thabi'iyyūn). (3) Filosof-filosof teis (ilahiyyūn). Kaum materialis dan naturalis merupakan orang yang memunyai ilmu pengetahuan, tetapi mengingkari dan durhaka kepada Tuhan, yang dimaksudkan al-Ghazālì kaum zindīq dan ahli juhūd. Dari sinilah bibitnya ilmu tanpa agama yang sangat berbahaya itu, dan membawa hanyut dunia kepada paham atheism. ${ }^{22}$

Sedangkan bencana yang ketiga yakni ilmu mazmūm (ethical-nihilism, ilmu pengetahuan tanpa moral), dalam buku al-Ghazālī yang berjudul Ihya' ' 'Ulum ad-Dīn, alGhazālī meletakkan soal ilmu pengetahuan di halaman yang paling depan. Ditegaskannya bahwa sebagai halnya jasmani memerlukan makan, jiwa memerlukan keimanan, maka makanan otak dan hati manusia adalah pengetahuan.

Segala sesuatu memerlukan akal, dan akal berhajat pada pelatihan dan pengembangan. Tiada kekayaan melebihi akal, dan tiada kefakiran yang melebihi kebodohan. Semakin banyak ilmu seseorang, maka semakin besar pula tuntutannya kepada akal. Bagi para ahli,

\footnotetext{
${ }^{19}$ Ibid., hlm. 145.

${ }^{20}$ Ibid., hlm. 168.

${ }^{21}$ Ibid., hlm. 82.

${ }^{22}$ Ibid.
} 
akal adalah bak seorang raja, akal banyak memiliki kepuasan, daya hapal, dan pemahaman. Kebahagiaan spiritual adalah akal, karena dengan dengan aspek fisik memperoleh kekuatan.

Bagi al-Ghazāili, ilmu dan akal tetap merupakan nilai-nilai agama yang adi luhung dan jalan menuju Tuhan, sedangkan pengetahuan dicapai melalui rasa $(\dot{z} a w q)$, dan pengalaman beribadahlah yang mengantarkan manusia kepada kepastian yang mutlak. ${ }^{23}$ Ilmu adalah kehidupan hati dari kebutaan, sinar penglihatan dari kegelapan dan kekuatan badan dari kelemahan yang menyampaikan hamba ke kedudukan orang-orang yang bijak dan sederajat yang tinggi. Ilmu itu pemimpin sedangkan amal itu adalah pengikutnya. Orang-orang yang berbahagia itu diberikan ilham mengenai ilmu dan orang-orang yang celaka itu terhalang. ${ }^{24}$

\section{Agama}

Agama merupakan bagian esensi paling dasar dari kehidupan manusia. Sebagaimana sebuah sistem kepercayaan, keberadaan agama telah muncul semenjak manusia itu diciptakan. Agama dapat menjadi penentu, termasuk dalam bidang politik, sekaligus sumber inspirasi dan pewarna peradaban. Dalam konteks yang lain, agama mampu menjadi faktor yang dominan sebagai penyulut konflik antarmanusia, bahkan sebagai pemecah belah peradaban manusia. Agama dapat didefinisikan sebagai suatu realisasi sosio-individu yang hidup (dalam ajaran, tingkah laku, ritus/upacara keagamaan dari suatu relasi dengan yang melampaui kodrat manusia dan dunianya, juga berlangsung lewat tradisi manusia dan dalam masyarakatnya ${ }^{25}$. Realisasi sosio-individu yang hidup ini, menciptakan suatu sistem yang mengatur makna atau nilai-nilai dalam kehidupan manusia yang digunakan sebagai kerangka acuan bagi seluruh realitas.

Iman merupakan komitmen dari agama, dapat dilihat melalui aktifitas atau prilaku individu dengan agama, keimanan sering diidentikan dengan keagamaan. Al-Ghazālī menegaskan bahwa iman adalah pembenaran yang mantap di dalam hati manusia, yang tidak ada keraguan lagi padanya, dan orang yang bersangkutan tidak merasa akan menjadi kekeliruan lagi di dalamnya. Dengan adanya pembenaran yang seperti itu dalam hati manusia, maka sudah dapat dibilang sebagai seorang mukmin di sisi Allah. Sedangkan pengakuan secara lisan merupakan penegasan iman dan keislamannya di sisi makhluk, dan pengalaman ajaran agama merupakan bagian pelengkap yang bisa menambah dan mengurangi kesempurnaan iman yang sudah ada. ${ }^{26}$

Allah telah memberikan nikmat kepada baginda. Ia telah menanamkan benih keimanan ke dalam lubuk hati baginda yang paling dalam. Ia menitipkan benih itu di relung hati baginda agar tumbuh subur. Ia menyuruh baginda menyiramnya dengan air kepatuhan, supaya benih itu tumbuh menjadi sebatang pohon yang akarnya menancap ke bumi, sedangkan cabangnya menjulang tinggi ke langit. Firman Allah: Tidakkah kamu perhatikan bagaimana Allah membuat perumpamaan, kalimat yang baik seperti pohon yang baik, yang akan kuat dan cabangnya akan menjulang tinggi kelangit. (Q.S. Ibrahim: 24). Jika akarnya tidak kuat oleh iman dan cabangnya tidak sempurna, pohon itu akan diterpa angin kematian dan kerusakan. Akhirnya, akarnya akan

${ }^{23}$ Antony Balack, Pemikiran Politik Islam: dari masa nabi hingga masa kini, terj. Abdulah Ali \& Mariana Ariestyawati, Jakarta: Serambi, 2006, hlm. 194.

${ }^{24}$ Al-Ghazālī, Ihyā', I, hlm. 40.

${ }^{25}$ Sudarmanto, Agama dan Politik Anti Kekerasan, Yogyakarta: Kanisius, 1989, hlm. 17.

${ }^{26}$ Zurkani Jahja, Teologi al-Ghazālì: Pendekatan Metodelogi, Yogyakarta; Pustaka Pelajar, 2009, hlm. 164. 
tercabut dan pohonnya akan roboh. Jika demikian, naużu bi Allah, ia akan mati tanpa iman dan menghadap hadirat Tuhan tanpa membawa kebajikan. ${ }^{27}$

Al-Ghazālī mengibaratkan iman memiliki sepuluh akar dan sepuluh cabang. Akar terkuat merupakan sebuah keyakinan di dada. Sedangkan cabangnya adalah ibadah. Segala pengetahuan dan keyakinan yang tertanam dalam hati merupakan pokok dasar dari iman itu sendiri. Tunduk dan berbuat adil merupakan cabang dari iman, apabila cabang itu kering, maka merupakan tanda dari kelemahan pada akarnya, apabila cabangnya mati maka akar atau pokoknya tidak kuat. Sedangkan perbuatan anggota badan merupakan tanda keimanan dalam hati.

Perbuatan-perbuatan yang merupakan cabang iman akan menjauhkan dari perbuatan haram dan mendorong pelaksanaan hal-hal wajib. Perbuatan itu ada dua. Pertama, perbuatan antara manusia dan Allah, diwujudkan dalam bentuk ketaatan terhadap perintah-Nya, menjauhkan diri dari larangan-Nya. Kedua, perbuatan antarmanusia. Semua itu bertujuan agar manusia selalu ingat akan Sang Pencipta. Bahwasannya, segala sesuatu yang kita lakukan di alam semesta ini atas kehendak-Nya. Dengan mengetahui cabang iman, al-Ghazāli bermaksud agar sang pemimpin kelak melakukan segala tugasnya sebagai seorang pemimpin, dilakukan dengan dasar keimanan.

Pemimpin yang mampu meningkatkan keimanannya, niscaya akan menerima warisan daya keimanan dari Rasulullah Saw, yang akan mengimami manusia dalam makna fisik, akan tetapi juga mengimami manusia dalam makna jiwa, akal pikiran, serta perilaku manusia kepada Allah dan Rasul-Nya. Dengan ini, akan memberikan efek silaturahmi yang kuat, persaudaraan, kesatuan, dan persatuan batin yang kuat dan kokoh dengan sesama makhluk. ${ }^{28}$

\section{Akhlak}

Misi utama kehadiran Muhammad ialah membangun kualitas moral. Seperti dalam hadis, "Aku diutus hanya untuk menyempurnakan keluhuran budi pekerti (akhlak alkarīmah)” (H.R Baihaqī). ${ }^{29}$ Akhlak merupakan hal yang sangat penting dan utama dalam Islam. Akhlak dapat dikatakan sebagai intisari dari buah agama. Alquran menyuruh manusia kepada kebaikan dan mencegah dari yang mungkar. Menyuruh bersikap adil, berbuat baik kepada orang lain, dan melarang berbuat zalim dalam bentuk apa pun dan kepada siapa pun.

Bagi al-Ghazālī, kekuatan moral adalah kemampuan untuk mengelola dan mengendalikan diri dari kecenderungan-kecenderungan yang bersifat destruktif. Jiwa manusia memiliki kesempurnaannya sendiri, sehingga selalu terbuka dengan perubahan dan perbaikan menuju puncak-puncak kemuliaan dan keluhuran budi pekerti. Disebut sebagai kekuatan moral apabila memiliki empat unsur sebagai berikut. Pertama, memiliki kekuatan yang kuat pada kebenaran dan kebaikan. Kedua, mampu mengidentifikasi apa yang baik dan apa yang buruk. Ketiga, mampu melakukan yang baik dan meninggalkan yang buruk. Keempat, mampu memengaruhi orang lain untuk berbuat baik dan mencegahnya dari keburukan. ${ }^{30}$

\footnotetext{
${ }^{27}$ Al-Ghazālī, At-Tibr al-Masbuk fi Nasihati al-Mulk, Libanon, Beruit, t.t.hlm. 6.

${ }^{28}$ Hamdani Bakran Adz-Dzakiey, Kepemimpinan Kenabian, Yogyakarta; al-Manar, 2009, hlm. 522.

${ }^{29}$ Baihaqī, Sunan al- Baihaqī al-Kubrā, juz I, hlm. 191.

${ }^{30}$ Ilyas Ismail, True Islam: Moral, Intelektual, Spiritual, Jakarta; Mitra Wacana Media, 2013, hlm. 27.
} 
Moralitas dan budi pekerti yang luhur berpangkal dari empat sifat: ${ }^{31}$ pertama, kearifan (hikmah), dipahami dari kata ثُ لم يرتابوا , iman yang kuat tidak disertai oleh keraguan merupakan keimanan dengan tingkat keyakinan yang kuat. Iman dicapai melalui ilmu dan wawasan yang luas dan mendalam, hakikat hikmah ialah ilmu yang mampu melahirkan amal kebaikan. Kedua, keberanian (syajā'ah), dipahami dari kata jihad, perjuangan di jalan Allah. Ketiga, kedermawanan (syakhāwah), dari kata بأمو لهم, puncak kedermawanan bagi al-Ghazālī dinamai $\bar{\imath} t \dot{s} \bar{a} r$, yaitu sikap mementingkan orang lain di atas kepentingan diri sendiri. Keempat, keadilan $(a l-a ́ d l)$, di balik sikap yang terpuji terkandung makna keadilan.

Ibadah dan kewajiban-kewajiban agama dalam Islam mengandung makna pendidikan akhlak. Dalam pandangan al-Ghazālī, ibadah-ibadah itu dimaksudkan sebagai sarana pembangunan akhlak, merupakan sarana latihan yang diulang-ulang untuk membiasakan manusia dapat hidup dengan memegang teguh akhlaq itu meskipun berbagai perubahan terjadi di depannya. ${ }^{32}$

Agar berpengaruh secara moral dan sosial, maka ibadah-ibadah itu tidak boleh dilakukan secara formalitas sekadar menggunakan kewajiban, tetapi perlu dilakukan dengan sikap batin yang kuat. Menurut al-Ghazālī, amal ibadah itu harus memenuhi dua kriteria sekaligus, yaitu kriteria syariat (Alquran dan Sunnah) dan kriteria hakikat, yakni Khudūr alQalb ma'a Allāh atau kesadaran ketuhanan. Kesadaran Ketuhanan adalah pangkal kebaikan dan keluhuran budi pekerti. Kesadaran ketuhanan bermakna kesadaran pada seseorang bahwa Tuahan selalu menyertai hidupnya, kehadiran ini yang akan menghindarkan manusia dari dosa-dosa dan pelanggaran moral. Kriteria ini merupakan kriteria yang bersifat batin (spiritual), tanpa sikap batin, perilaku lahiriyah belum merupakan hal yang sejati dalam agama, tanpa sikap batin yang kuat, pengalaman agama sehari-hari tidak mungkin memberikan dampak positif baik secara moral maupun sosial. ${ }^{33}$

Akhlak mulia merupakan satu di antara sifat pemimpin, para utusan Allah, akhlak yang baik menjadi bagian esensi agama dan buah dari kesungguhan orang yang bertakwa, dan menjadi pelatihan bagi orang-orang yang ahli dalam urusan ibadah. ${ }^{34}$ Akhlak yang buruk akan menjadi racun yang membunuh.

Definisi akhlak al-Ghazālī sejatinya merupakan respons terhadap definisi-definisi akhlak yang dikemukakan oleh ulama-ulama ketika itu. Menurutnya, "orang-orang (para ulama) memang telah membicarakan akhlak, akan tetapi sebenarnya tidak membicarakan hakikat akhlak, melainkan hanya 'buahnya' saja". ${ }^{35}$ Al-Ghazālī kemudian mengutip beberapa definisi akhlak yang dikemukakan oleh para ulama, antara lain:

Imam al-Hasan: akhlak baik adalah wajah yang manis, banyak memberi, dan mencegah hal-hal yang melukai orang lain. Al-Wasithi, akhlak baik adalah cerminan bilamana pemiliknya tidak suka bertengkar dengan sesama dan dimusuhi, karena kuatnya tingkatan ma'rifat kepada Allah. Imam Syah al-Karmani: akhlak baik ialah mencegah hal-hal yang menyakiti orang lain (terutama perasaan) dan penderitaan orang mukmin. Abu 'Utsman: akhlak baik adalah cermin dari mencari keridhaan Allah. Sahal al-Tusturi: akhlak baik adalah

\footnotetext{
${ }^{31}$ Ibid., hlm. 32-35.

${ }^{32}$ Ibid., hlm. 24.

${ }^{33}$ Ibid., hlm. 25-26.

${ }^{34}$ Al-Ghazālī, Ihyā' 'Ulum̄ ad-Dìn, III, Semarang: Toha Putra, t.t., hlm. 47.

${ }^{35}$ Al-Ghazālī, Keajaiban Hati, terj. Nurchikmah, Jakarta: Tintamas Indonesia, 1984, hlm. 140.
} 
apabila seseorang tidak salah sangka kepada Allah tentang rezeki, percaya kepada Allah bahwa rezekinya akan terjamin, tidak durhaka kepada Allah, dan menjaga hak-hak sesama. Sayyidina 'Ali ibn Thalib pernah berkata: "hakikat dari akhlak yang mulia itu ada pada tiga hal, yaitu: menjauhi segala yang haram, mencari yang halal, dan berlapang dada kepada sesama". Imam al-Husan bin Manshur: akhlak baik adalah apabila engkau tidak terpengaruhi oleh kekasaran perangai orang banyak setelah engkau mengetahui mana yang benar. Abu Sa'id al-Kharraz: akhlak yang baik ialah bilaman tidak ada suatu keinginan pun bagi hamba, selain bergantung kepada Allah. ${ }^{36}$

Definisi-definisi semacam inilah yang dikritik al-Ghazālī sebagai definisi yang terbatas pada buah akhlak, bukan pada substansinya. Untuk memperkuat alasannya, alGhazālī membedakan antara al-Khuluqu (budi pekerti) dan al-Khalqu (kejadian; bentuk lahir). Jadi yang dikehendaki oleh al-Khalqu meliputi "bentuk lahir", sementara al-Khuluqu menekankan pada "bentuk batin"-nya. Al-Ghazālī menambahkan bahwa al-Khuluqu menggambarkan perilaku yang meresap dalam jiwa (nafs), dan darinya memancarkan perbuatan-perbuatan yang tanpa melalui pikiran dan pertimbangan. ${ }^{37}$

Akhlak menjadi suatu ibarat tentang kondisi dalam jiwa yang menetap di dalamnya. Dari keadaan dalam jiwa itu kemudian muncul perbuatan-perbuatan dengan mudah, tanpa memerlukan pemikiran. Apabila aplikasi dari kondisi dimaksud muncul perbuatan-perbuatan baik dan terpuji secara akal dan syara', maka itu disebut dengan akhlak yang baik. Sedangkan perbuatan-perbuatan yang muncul dari kondisi yang dimaksud adalah suatu yang berdampak buruk, maka keadaan yang menjadi tempat munculnya perbuatan-perbuatan itu disebut sebagai akhlak yang buruk. ${ }^{38}$

Apabila mencermati definisi akhlak dan alat-alat untuk memperoleh ilmu, al-Ghazālī menekankan lebih menekankan pada kekuatan qalb. Qalb-lah yang menentukan apakah sikap dan perbuatan seseorang bisa dimasukkan dalam kategori akhlak, sebab akhlak menurut alGhazālī muncul tanpa melalui proses pertimbangan akal, apalagi pertimbangan panca indera. Jadi ilmu pengetahuan yang menggerakkan manusia untuk berakhlak muncul dari ilham dan $\dot{z} a \bar{u} q$ dalam pengertian yang lebih sederhana, bukan pengertian dunia sufistik. Pengetahuan yang melalui ilham dan $\dot{z} a \bar{u} q$ itulah yang seketika mendorong manusia untuk berakhlak baik, sehingga sikap dan perbuatannya mampu melintasi panca indera dan akal.

\section{KONSEP PEMIMPIN IDEAL MENURUT AL-GHAZĀLī}

Menurut ajaran Islam, pemimpin yang dianggap paling autentik adalah ulama sekaligus cendikiawan. Dalam perkembangan sosial politik umat, kepemimpinan yang demikian "agung", "suci", dan "sakral" sebagai satu-satunya sumber sosialisasi Islam, tempat lahirnya tafsir-tafsir Alquran atas pelbagai persoalan kontemporer umat manusia. ${ }^{39}$

Karakter pemimpin dalam Islam memiliki ciri khas yang tersendiri, karena dalam pemimpin dalam Islam membawa misi yang sangat besar dengan membawa nilai-nilai ajaran Islam, agar bisa diimplementasikan dalam pelbagai bidang dan dapat dirasakan kebaikannya bagi alam semesta. Ada beberapa karakter yang harus tumbuh dan berkembang dalam diri

\footnotetext{
${ }^{36}$ Al-Ghazāli, Ihyā, III, hlm. 52

${ }^{37}$ Musthofa, Akhlak Tasawuf, Bandung: Pustaka Setia, 1997, hlm. 11.

${ }^{38}$ Al-Ghazālī, Keajaiban, hlm. 52.

${ }^{39}$ Syaifuddin Jurdi, Pemikiran Politik Islam Indonesia, Yogyakarta; Pustaka Pelajar, 2008, hlm. 141.
} 
seorang pemimpin dalam melaksanakan amanah kepemimpinannya, yaitu: (1) Al- ' Ilm, orang yang berilmu. (2) Mukhlis, orang yang ikhlas. (3) 'Amil, orang yang giat bekerja.(4) Mujahid, orang yang selalu berjuang. (5) Mutady, orang yang senantiasa berkorban. (6) Mutajarrid, orang yang totalitas. (7) Musabit, orang yang teguh pendirian.

Kepemimpinan Islam berdiri di atas kepemimpinan Ketuhanan (ketauhidan), setiap manusia hanya tunduk dan patuh kepada kepemimpinan Allah Swt yang ditunjukkan oleh Nabi Muhammad Saw. Kerja kepemimpinan Muhammad merupakan wujud dan pesan-pesan kepemimpinan-Nya. Kepemimpinan dalam Islam tidak dibenarkan jika terdiri dari orangorang zalim, fasik, nifaq, kufur dan syirik (orang yang gemar melakukan dosa keji seperti zina, korupsi, manipulasi merebut kekuasaan dan sebagainya). Apabila terdapat seorang pemimpin yang seperti ini dalam Islam, maka eksistensi kepemimpinannya akan batal, tidak sah dan tidak memperoleh ketajallian Allah, syafa'at Rasul-Nya, serta restu penghuni bumi. ${ }^{40}$

Perkataan khalifah digunakan setelah wafatnya Rasulullah, terutama bagi keempat orang Khalifahur-Rasyidin, menyentuh juga maksud yang terkandung di dalam perkataan 'Amir', disebut juga penguasa. Oleh karena itu, kedua perkataan itu dalam bahasa Indonesia disebut pemimpin, yang cenderung berkonotasi sebagai pemimpin formal. Konotasi itu terlihat pada bidang yang dijelajahi di dalam tugas pokoknya yang menyentuh, tidak saja aspek-aspek pemerintahan dalam berbangsa dan bernegara, tetapi juga aspek-aspek keagamaan dalam bermasyarakat. ${ }^{41}$

Tugas manusia sebagai pemimpin untuk memakmurkan bumi ada dua. Pertama, menyeru dan menyuruh orang lain berbuat amal ma'ruf. Kedua, melarang atau menyuruh orang lain meninggalkan perbuatan munkar. Perbuatan manusia yang disebut kepemimpinan tidak pernah lepas dari perhatian dan penilaian Allah. Oleh karena itu secara spiritual, kepemimpinan harus diartikan sebagai kemampuan melaksanakan perintah dan meninggalkan larangan Allah, baik secara bersama-sama maupun perseorangan. Dengan kata lain kepemimpinan adalah kemampuan mewujudkan semua kehendak Allah yang telah diberitahukan-Nya melalui Rasulullah. ${ }^{42}$

Secara tidak langsung pemikiran yang gagas oleh al-Ghazālī dipakai oleh sebagian pemimpin-pemimpin di dunia ini. Pemimpin ideal yang di konsepkan al-Ghazālī sangat berguna untuk kelangsungan kepemimpinan yang efektif dan integrative. Seorang pemimpin yang diimpikan oleh masyarakat banyak. Pemimpin yang mampu membawa pengikutnya kepada kebahagiaan di dunia dan akhirat. Pemimpin yang membimbing ke jalan yang lurus, serta pemimpin yang mampu mewujudkan cita-cita bawahannya. Dari pembahasan panjang al-Ghazālī tentang pemimpin ideal di atas, memberikan konstribusi yang penting bagi pemimpin.

\footnotetext{
${ }^{40}$ Hamdani Bakran Adz-Dzakiey, Kepemimpinan Kenabian "Cara Menjadi Pemimpin dengan Keberkahan Allah, Syafaat Rasulullah, Restu Penghuni Langit dan Bumi”, Yogyakarta: al-Manar, 2009. hlm. 155-156.

41 Tobroni, The Spiritual Leadership: pengefektifan organisasi noble industry melalui prinsip-prinsip spiritual etis, Malang; UMM Press, 2010, hlm. 16.

${ }^{4}$ Ibid., hlm.16. 


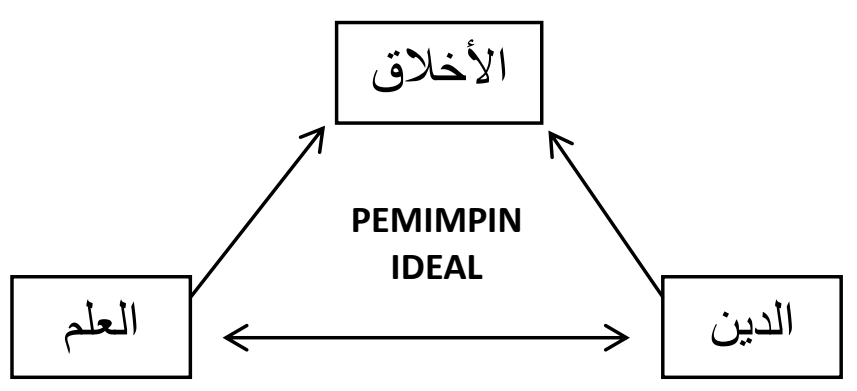

Dari gambar di atas dapat dijelaskan bahwa ilmu itu dituntun oleh jiwa keagamaan, akal yang dimiliki manusia yang membedakannya dari hewan dan makhluk lain, merupakan bawaan manusia semenjak lahir. Akal yang dipergunakan dengan berjalannya waktu, melewati sebuah pembelajaran (dari agama yang menjadikannya petunjuk) dan pengalaman melahirkan sebuah ilmu pengetahuan. Dengan agama manusia berilmu, dengan ilmu dapat memahami agama, agama yang menjadi peraturan dan petunjuk hidup dapat dijalani dengan ilmu, karena ilmu adalah jalan mencapai kebahagiaan dunia dan akhirat. Tanpa agama manusia akan tersesat, yang berhujung pada matinya hati. Tanpa ilmu, jiwa akan sakit kemudian mati, makanan dari jiwa adalah ilmu. ${ }^{43}$ Agama menuntun kepada kebahagiaan dunia dan akhirat, dengan kesempurnaan akal dan pikiran. Dengan agama dan ilmu mampu membimbing kepada akhlak yang terpuji, menghindari dari perbuatan tercela. Akhlak yang mulia akan memberikan efek baik dan bagus terhadap agama dan ilmu. Relasi erat antara agama, ilmu, dan akhlak, di mana dari penggabungan itu akan melahirkan ma'rifah yang menjadi tingkatan tertinggi dari pengetahuan dan kesadaran rohani manusia kepada Tuhan. Nilai agama yang diyakini bersumber dari Tuhan dijadikan kerangka acuan seluruh realitas (dunia maupun akhirat).

Pengetahuan bagi seorang pemimpin merupakan hal yang wajib fardu'ain untuk dimiliki, tidak hanya pada seorang pemimpin, tetapi ilmu pengetahuan juga merupakan kewajian bagi seorang Muslim. Dengan belajar akan membebaskan dari kebodohan dan kegelapan, serta membawa pada kehidupan yang diterangi oleh iman dan ilmu pengetahuan. Pengetahuan dapat memahami bagaimana mengembangkan dan menggunakan pikirannya dengan baik, tersistem, efektif, dan efisien, serta dapat berpikir secara kreatif-inovatif yang bersifat pragmatis dan produktif. Dengan pengetahuan dapat memahami dengan baik manfaat berpikir proaktif (cara berpikir yang menandakan adanya kemauan baik, serta semangat untuk maju dan sukses) dan sinergetik (cara berpikir yang menandakan bahwa seseorang memperhitungkan segala faktor yang terkait dan saling memengaruhi/bekerja sama yang mendukung ke arah keberhasilan), sehingga mampu membuat keputusan dengan tepat, jelas, dan berdaya. Apabila pengetahuan pemimpin itu itu masih kurang, menjadikan pemimpin itu berpikiran sempit yang mengakibatkan terjadinya kerusakan.

\section{PENUTUP}

Sosok pemimpin ideal yang dikonsepkan al-Ghazālī adalah pemimpin yang tertanam dalam dirinya ilmu pengetahuan, agama, dan akhlak. Keseimbangan ilmu pengetahuan, agama, dan akhlak yang mampu membawa pemimpin menjadi pemimpin ideal, apabila dari

\footnotetext{
${ }^{43}$ Al-Ghazālì, Ihyā'; I, hlm. 8.
} 
ilmu pengetahuan dengan agama ini ada yang mendominan, maka akhlak mulia tidak akan tumbuh, bila pengetahuan dan agama terputus akan menjadikan kehancuran. Ketika tiga poin itu ada pada seorang pemimpin kejayaan, kemakmuran, kebahagiaan, kesejahteraan akan datang, seperti masa jayanya Islam di masa Nabi Muhammad Saw. Agama tanpa ilmu pengetahuan, yang menyebabkan bencana pada kepemimpinan, Iman dicapai melalui ilmu dan wawasan yang luas dan mendalam, tanpa sikap batin, perilaku lahiriyah belum merupakan hal yang sejati dalam agama, tanpa sikap batin yang kuat, pengalaman agama sehari-hari tidak mungkin memberikan dampak positif baik secara moral maupun sosial. Dalam Kitab Ihyā' 'Ulum ad-Dīn, al-Ghazālī berpesan:

Sesungguhnya, kerusakan rakyat disebabkan oleh kerusakan para penguasanya, dan kerusakan penguasa disebabkan oleh kerusakan ulama, dan kerusakan ulama disebabkan oleh cinta harta dan kedudukan, dan barang siapa dikuasai oleh ambisi duniawi, ia tidak akan mampu mengurus rakyat kecil, apalagi penguasanya. Allah lah tempat meminta segala hal. ${ }^{44}$

Beberapa poin penting mengenai kepemimpinan ideal dalam Islam, bahwasannya pemimpin adalah seorang pekerja yang ideal, di mana modal utama bagi seorang pekerja ideal adalah 'Ilm (knowledge) yang bersumber pada Alquran, Hadis, dan literatur Islam, Iman (faith) berupa ketaqwaan pada Allah dan A'mal (deed) dalam bentuk shalat dengan khusyu. Kualitas dasar bagi seorang pemimpin ideal adalah berani, tulus hati, ramah dan santun, teratur, teguh, pekerja keras, disiplin, kemampuan memimpin dengan baik, memiliki kebiadaan yang baik, kemampuan berbicara dan menulis yang baik. Sedangkan modal untuk peningkatan kualitas adalah sabr (sabar), hikmah (bijaksana), tawakkal (yakin dan berserah diri kepada Allah), Bai'yah (Janji setia kepada Allah), dan Ihtisab (jiwa tanggung jawab). ${ }^{45}$

\section{DAFTAR PUSTAKA}

Adz-Dzakiey, Hamdani Bakran, Kepemimpinan Kenabian "Cara Menjadi Pemimpin dengan Keberkahan Allah, Syafaat Rasulullah, Restu Penghuni Langit dan Bumi", Yogyakarta; al-Manar, 2009.

Ahamad, Zainal Abidin, Konsepsi Negara Bermoral Menurut Imam al-Ghazālī, Jakarta; Bulan Bintang, 1975.

Al-Ghazālī, Ihya' Ulumuddin, II, Beirut: Dar Kutub al-Ilmiyah, t.t. , Ihyā' 'Ulum ad-Dīn, I, Semarang: Toha Putra, t.t. , Ihyā' 'Ulum ad-Dīn, III, Semarang: Toha Putra, t.t. , Keajaiban Hati, terj. Nurchikmah, Jakarta: Tintamas Indonesia, 1984.

Alquran Karim dan Terjemahannya, Yogyakarta: UII Perss, 1999.

Black, Antony, Pemikiran Politik Islam: Dari Masa Nabi Hingga Masa Kini, terj. Abdulah Ali \& Mariana Ariestyawati, Jakarta: Serambi Ilmu, 2006.

Ensiklopedi Islam Indonesia, Jakarta: Djambatan, 1992.

First Encyclopedia of Islam, 1913-1936, New York-Leiden: Brill, 1987.

Ismail, Ilyas, True Islam: Moral, Intelektual, Spiritual, Jakarta: Mitra Wacana Media, 2013.

\footnotetext{
${ }^{44}$ Al-Ghazali, Ihyā', II, hlm. 381.

45 Jamalulail Yunus, Leadhership Model: Konsep Dasar, Dimensi Kerja, dan Gaya Kepemimpinan, Malang; UIN-Malang, 2009, cet. I, hlm. 35.
} 
Jahja, Zurkani, Teologi al-Ghazālī; Pendekatan Metodelogi, Yogyakarta: Pustaka Pelajar, 2009.

Jurdi, Syaifuddin, Pemikiran Politik Islam Indonesia, Yogyakarta: Pustaka Pelajar, 2008.

Kartono, Kartono, Pemimpin dan Kepemimpinan, cet. 19, Jakarta: Raja Grafindo Persada, 2013.

Tobroni, The Spiritual Leadership: Pengefektifan Organisasi Noble Industry Melalui Prinsipprinsip Spiritual Etis, Malang: UMM Press, 2010.

Yunus, Jamalulail, Leadhership Model: Konsep Dasar, Dimensi Kerja, dan Gaya Kepemimpinan, cet. I, Malang: UIN-Malang, 2009. 